ESJ Social Sciences

\title{
Effect of Exchange Rate Misalignment on Bilateral Trade Between Kenya and European Union: 2000-2016
}

\author{
Charles Munene Gachoki \\ Susan Okeri \\ Julius Korir
}

School of Economics, Kenyatta University, Nairobi, Kenya

Doi:10.19044/esj.2021.v17n41p58

Submitted: 25 August 2021

Accepted: 01 December 2021

Published: 31 December 2021

\author{
Copyright 2021 Author(s) \\ Under Creative Commons BY-NC-ND \\ 4.0 OPEN ACCESS
}

Cite As:

Gachoki C.M., Okeri S. \& Korir J. (2021). Effect of Exchange Rate Misalignment on Bilateral Trade Between Kenya and European Union: 2000-2016. European Scientific Journal, ESJ, 17 (41), 58. https://doi.org/10.19044/esj.2021.v17n41p58

\begin{abstract}
The exchange rate is an important variable in international trade because a country's competitiveness is determined by the expectations on how trade reacts to its movements. To orient the economy outwards, Kenya has pursued various measures from the 1990s to the 2000s. Kenya also signed up for nonreciprocal trade with the European Union under the Cotonou agreement. Despite the export-oriented efforts, Kenya's trade has remained skewed towards imports and a widening trade deficit which seems to follow the weakening of the Kenya shilling. The main policy dilemma therefore, is how imports accelerated in an environment of unhindered European Union market access, hence the motivation of this study. The study adopted a dynamic modeling approach since previous and present values affect exchange rate and trade. The results show that the economic fundamentals drive the real exchange rate. In terms of misalignment, the exchange rate is overvalued to a maximum of 5.9 percent and undervalued up to 5.2 percent. The estimated misalignment hurts imports but has a positive, statistically insignificant effect on exports. The results of this study suggest that the monetary authority should ensure the exchange rate remains stable and within the 6 percent range while monitoring all the underlying determinants. Additionally, hedging instruments should be made available and affordable to traders.
\end{abstract}


Keywords: Misalignment, trade flows, exports, imports

\section{Introduction}

A country's exchange rate is the domestic currency expressed in terms of a foreign currency. The rate frequently varies at the foreign exchange markets. It is an essential variable in the economic processes both from a descriptive and policy perspective. Due to its administrative simplicity, it has emerged as a significant tool in the arsenal of economic management policies. Thus, a country's exchange rate affects the actual economic variables and monetary variables. The stability of a country's exchange rate and its level relative to its equilibrium level affects the growth and volume of trade (Bahmani, Harvey \& Hegerty, 2012). A country's exchange rate is a crucial variable because trade reacts to fluctuations that alter the structure of prices and incentives in trading activities hence the whole economy. For instance, exports of developing countries decline with exchange rate movements while those of developed countries remain unaffected (Mukherjee \& Pozo, 2007).

The effect of the exchange rate movement on trade varies from countries and regions. Empirical studies record a higher exchange rates volatility in developing countries of Latin America and Africa compared to Asia. Also, volatility in developing countries is four times that of developed countries. Other studies show that the magnitude of volatility depends on the degree of flexibility of the exchange rate regime. Countries operating flexible exchange rate regimes experience twice the volatility experienced in countries operating hard pegs or fixed regimes regardless of their development status (Calderon, Chong \& Loayza, 2002). Generally, developing countries exhibit three times more exchange rate volatility than their developed counterparts. The high volatility in developing countries is blamed on the lack of management resources. Where the resources exist to relieve the risk effects, in the short run, they are too complicated and not all round hence limited in their functions. The application of such tools is also hindered by their cost, especially to small firms, particularly in the case of high volatility (HutchetBourdon \& Korinek, 2011). Therefore, unless traders hedge themselves in the forward market, they have to bear exchange rate risk on commitments to pay or receive foreign currency in the future.

Among the reasons a country's real exchange rate (RER) can move upward is the appreciation of the nominal exchange rate, the depreciation of other countries' currencies, or a greater rate of domestic inflation rate relative to a foreign counterpart (Balassa, 1964). The remedy to the resultant price competitiveness loss would be to reduce the domestic inflation rate or currency depreciation as compensation for its relatively higher costs. However, inflation is not the only reason for an exchange rate adjustment in developing countries. For instance, policymakers in developing countries may 
be aligning the domestic economy to changes in the international market, such as a decline in export earnings which negatively affect the balance of payments. Policymakers have had an extensive debate over the suitable level of a country's exchange rate. According to Bird (1998), a multilateral agencies standard posits that a country's exchange rate should favor the growth of exports and be consistent with normal and expected capital flows over the medium-term current account position.

Exchange rate misalignment is represented by the deviation of the real exchange rate from its long-run equilibrium path, which distorts the comparative advantage -the core of the Ricardian theory of international trade. Arize, Osang and Slottje (2008) argues that failure to include a variable that captures the influence of exchange rate risks such as exchange rate misalignment in a study of international trade determinants may yield a bias of potentially mis-specified results. According to Edwards (1997), the operational definition of the real exchange rate is given by: $R E R=\frac{E P_{T}}{P_{N T}}$

where $R E R$ is the real exchange rate, $E$ is the exchange rate, $\mathrm{P}_{\mathrm{T}}$ is the world price of tradeable (proxied by wholesale prices), and $P_{N T}$ is the price of non-tradeable (proxied by a domestic price index). Thus, the unobservable gap between the exchange rate and its equilibrium level is the exchange rate misalignment. The exchange rate can be overvalued or undervalued if it appreciates or depreciates over or under its equilibrium path. Exchange Misalignment is associated with markets where the actual exchange rate cannot adjust to changes in the underlying economic fundamentals. The causes of exchange rate misalignment are unsustainable monetary and fiscal policy alongside unsustainable trade and exchange control policies.

A correctly aligned exchange rate is an important issue in developing countries where their chief foreign exchange earner is agriculture as the engine of the economies, especially in employment. While the government's manufacturing sector in these countries is protected, their agricultural enterprises remain largely exposed (Csermely, 1994). The problem can be compounded when currencies in developing countries become overvalued, reducing the profitability of agricultural tradeable and negatively affecting agricultural performance. Therefore, a steady exchange rate is a crucial variable in the growth of a country's trade.

Arguably, a country's RER misalignment has a dual effect. It enhances the profits to traders and is an incentive to non-traditional and potential goods of exports that may encounter increased barriers of entry due to a disproportionately highly valued currency (Calamitsis, Basu \& Ghura, 1999). An overvalued exchange rate is considered a more significant threat to an economy than an undervalued exchange rate. Imports are encouraged while exports are undermined in an overvalued exchange rate environment because 
competitiveness is lost by reducing the incentives of the importing country to import (Gaalya, Edward \& Eria, 2017). If this situation persists, exports decrease relative to imports. This resultant increase in imports requires the additional foreign exchange and may lead to increased borrowing to reduce foreign exchange reserves. Thus, it is key to determine when an overvaluation of the exchange rate occurs as this is considered the leading cause of economic damage.

One crucial indicator of a country's economic vulnerability is exchange rate misalignment (Lugaiyamu, 2015). A persistent exchange rate overvaluation is regarded as a precursor to a crisis and reflects unsustainable macroeconomic policies in the economy. Conversely, a persistent undervaluation could cause the economy to overheat. This further exerts pressure on domestic prices and misallocation of resources between tradeable and non-tradeable sectors. Rodric (2008) suggests that, by carefully crafting an exchange rate undervaluation, China, Taiwan, Tanzania, and Uganda seem to have resolved or cushioned themselves against the weak institutions' constraint. Although most countries outside Sub-Saharan Africa have dealt well with overvaluation, the exchange rate is overvalued due to inappropriate and inconsistent policies. For instance, while a stable undervalued exchange rate is a viable policy for economic growth in developing countries, maintaining the policy long enough can have negative repercussions and, therefore, become insufficient (World Bank, 2012). The experience from the high-performing East Asian "success stories" countries shows that a sound exchange rate induced competitiveness is one of the "winning strategies" in an export-oriented world.

The equilibrium RER exists when the relative price of tradeables to nontradeables is such that it leads to a simultaneously internal and external equilibrium. A country's exchange rate can be affected by variable changes that affect the country's internal and external equilibriums. These include the world price of exports, import tariffs, and real interest rates. In addition to the real exchange rate, all the real variables that determine a country's internal and external equilibrium are real exchange rate fundamentals, whose current and expected future values affect the real exchange rate equilibrium (Edwards, 1989). The external fundamentals include international terms of trade, international transfers, foreign aid flows, and the world's real interest rates. The internal fundamentals are categorized into decisions related to policy and those that are unrelated to policy. The policy-related fundamentals include import tariffs and quotas, export taxes, exchange and capital controls, and composition of government expenditure (Naseem, Tan \& Hamizah, 2009). The non-policy fundamentals include technological progress.

Over time, researchers have considered more fundamental determinants of the exchange rate in their studies. Theoretically, there is a 
positive correlation between the actual oil price and the exchange rate (Lugaiyamu, 2015). Because oil imports cannot be substituted by domestic residents with other locally produced energy sources, disposable income is reduced by increasing the price of oil. Consequently, the demand for domestic goods falls, which leads to a decline in prices; hence the real exchange rate depreciates. The level of net foreign assets (NFA) affects the current account in two opposing ways. A negative association between NFA and the current account can exist where a country remains solvent due to high NFA, which leads to longer-term trade deficits. In addition, higher net foreign income flows accrue to economies with high NFA; hence, the NFA and current account balances are positively related.

\subsection{Kenya's Exchange Rate and Trade with European Union}

Kenya's foreign exchange market was liberalized in the 1990s in a gradual movement to a floating exchange rate regime from a fixed to a floating exchange rate regime. The liberalization in independent Kenya began in 1963 to 1982 with a fixed exchange rate regime, a crawling peg period from 1983 to 1993 , and in 1993, and eventually embracing a floating exchange rate regime. A dual exchange rate that lasted up to 1993 was preceded by a crawling peg period from 1982 to 1990 . However, the exchange rate misalignment triggered the abandonment of the dual exchange rate. The environment of floating the exchange rate was characterized by enormous depreciation such that in 1993 there were three episodes of exchange rate devaluation.

By 2016, Kenya's key export destination was Africa accounting for 40.6 percent of total exports. The leading exports included tea, coffee, horticulture, apparel, and clothing. Exports amounting to 24.5 percent of the total exports went to Europe, with the bulk of it destined to European Union (EU). Asia remained the single dominant source of Kenya's imports accounting for 66.8 percent of total imports in value, in 2016 (Republic of Kenya 2017). Kenya's key imports include motor cars and parts, veterinary and human medicine, agrochemicals, rubber, steel and iron products, fuels and lubricants, computing equipment, electrical and electronic equipment sourced from EU as the largest market origin (Nkoro \& Uko, 2016). Furthermore, Kenya-EU trade is second only to COMESA by rank. Kenya's primary export destinations are France, Germany, the United Kingdom, and the Netherlands. E.U. imports primary agricultural goods from Kenya such as fruits, vegetables, and cut flowers and account for approximately 90 percent of total exports value.

The nonreciprocal agreement (Cotonou, 2000) allowed the EU to maintain preferential access to the European market by the African, Caribbean, and Pacific (ACP) countries, in return for reduced customs duties for European exports. For the East African Community (EAC) member 
countries, this agreement formally came to a close in 2014 and was supposed to be succeeded by the Economic Partnership Agreements (EPAs). The new agreement seeks to establish a Free Trade Area (FTA) between EU and ACP countries in their economic groupings. The ACP countries must open up their markets to EU products while considering their diverse needs and differentiated levels of development. Based on this arrangement, countries were expected to open up market access only when they were ready.

The year 2014 marked the end of the nonreciprocal trade arrangement between E.U. and its ACP partners. This trade framework guided by Yaoundé, Lomé, and Cotonou agreements ended in 2007 when the World Trade Organization terminated the second waiver. The waiver had permitted the EU to differentiate trade engagements with the ACP partners from the other developing countries. Consequently, it was a requirement for ACP countries for the first time to engage in reciprocal, though asymmetric trade agreements with a developed and major trading partner while their regional integration was basically in a formative stage. The EPAs were to be negotiated at a regional level as development tools in building strong regional markets, enhancing trade and investment, facilitating the integration of ACP economies in the global economy, and motivating deeper economic reforms. Additionally, they were meant to ensure unlimited, immediate, fully liberalized ACP market access to the EU market and opened the services market.

However, it was evident to the least developed ACP partners that there was no meaningful gain from the EU market access since 2001. They also feared losing import duty revenues, unfair competition from subsidized European agriculture, and crowding small businesses from an already weak manufacturing sector due to competition from Eurozone products. In addition, they were faced with a no-deal with the EU that meant they would have been worse off by competing with all other developing countries in the absence of Cotonou preferences. The latitude of the agreement was revised to include trade in goods only with a commitment to have services negotiations in the future. Compared to the ACP-EU agreement, the EPAs included more products. A relaxation of the rules of origin allowed countries to source products from neighbouring countries, transform them locally, and still qualify for exports to the E.U. (World Bank, 2012).

The EPAs have also had challenges because possibilities favour some regions more than others and failure to address administrative customs cooperation. Further, liberalization was to be phased over at 25 years. Due to the sensitivity of agricultural products, the sector was not subject to liberalization. Despite the envisaged gains from the ACP-EU and the proposed EPAs, these agreements do not consider the nature of trade in commodities and the outcomes of such market openness on developing countries. Kenya's 
trade flows, for instance, present a unique production structure in the agriculture and manufacturing sector where agricultural exports are primarily bound to the E.U while the industrial goods are headed to the region (World Bank, 2012).

\subsection{Kenya's Exchange Rate Misalignment and trade}

Exchange rate misalignment, which characterized the period of the dual exchange rate from 1990 to 1993 in Kenya, led to the abandonment of the official exchange rate. Adopting the flexible exchange rate was expected to raise the price of exportable relative to non-tradeable, thereby motivating exports through the interplay of market forces of demand and supply for foreign exchange (Mwega, 2014). Figure 1. shows the trend of Kenya's exchange rate and trade balance with EU between January 2000 and 2016. This period is important because the ACP-EU Partnership Agreement was signed in 2000 for 20 years, covering 2000 to 2020 and allowing nonreciprocal access of ACP goods to the EU market.

Figure 1. Kenya's Exchange Rate and Trade Balance With EU

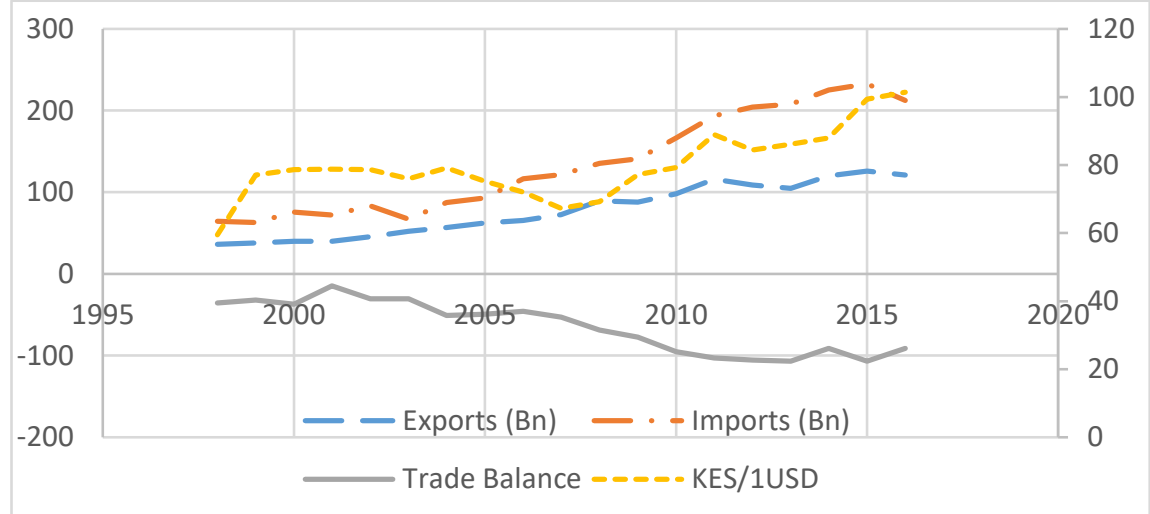

Source: Author's compilation using data from Central Bank of Kenya statistics (2000-2016)

Between 2000 and 2004, imports and exports between Kenya and EU moved closer together. EU Imports dipped in 2003 due to slowed growth in the Euro region from 0.9 percent in 2002 to 0.5 percent in 2003. Although exports and imports increased between 2004 and 2008, the trade deficit widened from 0.82 percent GDP in 2004 to 10 percent in 2012. This could be explained by a boost in household spending due to an improved labor market that saw unemployment drop by 8 percent since 2001 (Republic of Kenya 2007). Beyond 2009 imports accelerated, and the trade deficit between Kenya and EU expanded. The growth of exports in 2010 was attributed to Spain, Italy, Belgium, and the United Kingdom markets, where exports increased by 34.9, 34.6, 22.7, and 4.5 percent, respectively, in 2010. As a single market, the exports to the EU rose by 7.3 percent. They accounted for 24.1 percent of the 
total export earnings in 2010, partly due to increased horticultural, fish exports and global prices (Republic of Kenya 2012). However, this could not match airplane imports, and other aircraft, electrical generating sets, and rotary converter that tripled in 2010. The notable dip in exports in 2013 was due to a fall in international prices for tea, coffee, and horticultural products. The poor weather pattern also led to a fall in the total value of marketed output in tea, cut flowers, fruits, and coffee (Republic of Kenya 2014). The country's export structure has remained constant, with the same raw agricultural goods exported and a fixed set of countries.

Between 2000 and 2004, Kenya's exchange rate stabilized at around $80 \mathrm{KES} / \mathrm{USD}$. This was trailed by a 15 percent appreciation from 2004 to 2007 when the annual average dropped from 79.2 to $67.3 \mathrm{KES} / \mathrm{USD}$. The improved macroeconomic environment of 2004-2007 that characterized the NARC government can be attributed to the appreciation of the Kenya Shilling (KES), which reduced Kenya's competitiveness and encouraged imports to compete with local output. A depreciation from 2008 onwards followed this appreciation credited to the 2007/08 global financial crisis, among other external shocks. In 2011, the exchange rate appreciated briefly due to a gradual monetary policy tightening aimed at stabilizing the exchange rate (Republic of Kenya 2012). In 2014, the KES weakened against the USD by 2.1 percent. This depreciation happened against a fall in oil prices, increased diaspora remittances, and a \$2 billion injection from floating off the Eurobond. According to the Republic of Kenya (2015), the depreciation was due to the strengthening of the Dollar; declining international visitors that deteriorated tourism earning; and a widening trade deficit. For the given merchandise imports, Kenya's oil imports account for over 20 percent of the total. Kiptui and Kipyegon (2008) argued that the increased oil prices in the world market could have been transmitted to domestic prices hence depreciating the local currency.

The period between 2000-2016 saw the exchange rate appreciate and depreciate at various times. Oiro (2015) argues that these episodes were accompanied by wild exchange rate fluctuations, leading to the high exchange rate volatility, mainly driven by inflation and trade deficit. Other researchers observed that Kenya's exchange rate had been misaligned with changing extents (Kiptui \& Kipyegon, 2008). Therefore, the main policy dilemma is how imports accelerated in an environment of unhindered EU market access through the ACP agreement and liberalization of the exchange rate, whose aim was to improve exports. Due to this dilemma and the fact that trade between Kenya and EU in expressed in USD, it is necessary to investigate the relationship between the KES exchange rate and her trade with EU. Such a study would inform future trade agreements between Kenya and a bigger 
economy, especially in negotiations between Kenya and E.U. in the EPA framework.

\subsection{Research Questions}

The main aim of the study was to answer the following research questions:

i. What is the extent of Kenya's exchange rate misalignment?

ii. What is the effect of exchange rate misalignment on bilateral trade flows between Kenya and EU?

\subsection{Review of Related Literature}

\subsection{The Monetary Theory - The Dornbusch Sticky Prices Model}

The model argues that in the presence of an expansionary monetary shock, the exchange rate overshoots in the short term and reverts to its longrun equilibrium path. The model assumes a small economy operating in a flexible exchange rate, with sticky short-term prices and rational expectations in the goods market. Given a monetary policy change such as an increase in interest rate, the goods, and financial market adjust to the new equilibrium. However, equilibrium is reached first in the financial market since prices are sticky in the goods market. Ultimately, when the goods and services prices progressively respond to the new equilibrium, the exchange rate overshoots in the short run, creating excess volatility. The model can be derived as:

$$
\begin{array}{cc}
m_{t}-p_{t}=\gamma y_{t}-\theta i_{t} \text { domestic money market equilibrium } & 2.1 \\
m_{t}^{*}-p_{t}^{*}=\gamma y_{t}^{*}-\theta i_{t}^{*} \text { foreign money market } & 2.2 \\
s_{t}=p_{t}-p_{t}^{*} \text { purchasing power parity (PPP) } & 2.3 \\
i_{t}-i_{t}^{*}=E_{t} s_{t+1}-s_{t} \text { uncovered interest rate parity (UIP) } & 2.4
\end{array}
$$

Where: $m_{t}$ and $m_{t}^{*}$ are the domestic and foreign money supply, $p_{t}$ and $p_{t}^{*}$ are the domestic and foreign price levels, $y_{t}$ and $y_{t}^{*}$ are the domestic and foreign incomes, $i_{t}$ and $i_{t}^{*}$ represent domestic and foreign interest rates, and $s_{t}$ is the nominal exchange rate all in their natural $\log$. $E_{t} s_{t+1}$ is the expectation of $s_{t+1}$ at time t, $\gamma$ is the income elasticity of demand, and $\theta$ is the coefficient of adjustment of the present exchange rate to its long-term price. Combining 2.2 and 2.3 and substituting the PPP yields:

$$
s_{t}=m_{t}-m_{t}^{*}-\gamma\left(y_{t}-y_{t}^{*}\right)+\theta\left(i_{t}-i_{t}^{*}\right)
$$

Let $F_{t}=m_{t}-m_{t}^{*}-\gamma\left(y_{t}-y_{t}^{*}\right)$ represent domestic and foreign countries money supply and prices, respectively. Substituting UIP into 2.5: $s_{t}=F_{t}+$

$$
\theta\left(E_{t} s_{t+1}-s_{t}\right)
$$

Assuming rational expectations and no bubble solution $s_{t}$ can be solved as:

$$
s_{t}=\frac{1}{1+\varnothing} \sum_{j=0}^{\infty}\left(\frac{\emptyset}{1+\varnothing}\right)^{j} E_{t}\left[\sum_{j=0}^{\infty} F_{t+j}\right]
$$

Equation 2.7 is a relationship between the sum of expected future fundamentals such as money supply shocks, money demand shocks, and 
productivity shocks, among others, and the exchange rate. $F_{t}$ includes both observable and unobservable components of the macroeconomic fundamentals. This is the monetary approach foundational model used in forecasting exchange rates. The sticky-price model assumes that exchange rates do not change simultaneously as the underlying macroeconomic variables. The model was extended by Siregar (2011) using the Behavioral Equilibrium Exchange Rate (BEER) approach and the concept of uncovered interest rate parity: $i_{t}-i_{t}^{*}=E_{t}\left(e_{t+1}\right)-e_{t} \quad 2.8$ $e_{t+1}$ is the expected value of the nominal exchange rate in period $t$ for $t+1$ period and $e_{t}$ represents the nominal exchange rate in period $t . i_{t}-i_{t}^{*}$ represents the local and foreign interest rate differential. By subtracting the expected inflation from both sides of equation 2.8 transforms the nominal interest rate parity into the real interest parity.

$$
\begin{aligned}
& \left(E_{t}\left(p_{t+1}\right)-p_{t}\right)-\left(E_{t}\left(p_{t+1}^{*}\right)-p_{t}^{*}\right)=E_{t} \Delta p_{t+1}-E_{t} \Delta p_{t+1}^{*} \\
& \text { leads to } E q_{t+1}-q_{t}=r_{t}-r_{t}^{*}
\end{aligned}
$$

where $E q_{t+1}$ is the real exchange rate at period $t$ for period $t+1, q_{t}$ is the observed real exchange rate, $p_{t}$ and $p_{t}^{*}$ are the domestic and foreign prices respectively, $r_{t}$ and $r_{t}^{*}$ are the domestic and foreign interest rates at period t, where $r_{t}=i_{t}-E_{t}\left(\Delta p_{t+1}\right)$ and $r_{t}^{*}=i_{t}^{*}-E_{t}\left(\Delta p_{t+1}^{*}\right), \Delta p_{t+1}$ and $\Delta p_{t+1}^{*}$ is the change in domestic and foreign prices, respectively. From 2.10: $q_{t}=$

$$
E q_{t+1}-\left(r_{t}-r_{t}^{*}\right) \quad 2.11
$$

This implies that the observed real exchange rate can be expressed in the expected real exchange rate and real interest rate differential. In other words, equilibrium real exchange rate can be estimated from the BEER approach by incorporating long-run economic fundamentals and short-run interest rate differential expressed as:

$$
q_{t}^{r e r}=f\left(F_{t}, r_{t}-r_{t}^{*}\right)
$$

Where $F_{t}$ is the observable and unobservable components of the fundamentals derived in 2.7 .

\subsection{The Elasticity Theory}

The Elasticity theory predicts how the devaluation of a country's currency affects the balance of payments and the ideal conditions for the devaluation. The approach assumes that devaluation can improve the balance of payments starting from a balance of payment equilibrium point. However, for devaluation to function successfully, the total price elasticity of domestic and foreign demand for imports in absolute terms has to increase. When a country devalues a currency, it improves the balance of payments under ideal (Marshall-Lerner) conditions (ML-C). As a devaluation of the exchange rate implies a decrease in export prices, they increase in quantity. Concurrently, the price of imports increases, shrinking their demand. The import and export price elasticity results from the greater export volume at lower prices and 
fewer imports. If export prices are elastic, the export demand will exceed the price decrease, therefore growing the general receipts from exports. The elasticity approach has undergone many improvements and modifications towards explaining international trade, particularly in the structural economic estimation of price and income elasticities of imports.

Hacker and Hatemi (2004) linearized the elasticity theory by postulating that imports are a function of relative prices (R.P.) and the size of the economy (Y). $M_{d}=M_{d}\left(R P_{m}, Y\right)$

$M_{d}$ is the imports demand, $R P_{m}$ is the relative price of imports, and $\mathrm{Y}$ is the domestic income of the importing country. Supposing $e$ is the nominal exchange rate, then the relative price of imports can be written as: $R P_{m}=$

$$
e \frac{P_{X}^{*}}{p}=e \frac{P^{*}}{P} \cdot \frac{P_{X}^{*}}{P^{*}}
$$

$\mathrm{P}$ and $\mathrm{P}^{*}$ are the domestic and foreign prices, respectively, $e$ is the nominal exchange rate, subscript $\mathrm{x}$ shows the goods were exports in the foreign country such that $\frac{P_{x}^{*}}{P^{*}}$ is the relative price of exports in the foreign country denoted $R P_{x}^{*}$. Let $E$ be $e \frac{P^{*}}{P}$ (the real exchange rate). Substituting in 2.14: $R P_{m}=E \cdot R P_{x}^{*}$

Substituting 2.15 into 2.13: $M_{d}=M_{d}\left(E, R P_{x}^{*}, Y\right)$

\subsection{Empirical Literature Review}

There exist several empirical studies estimating exchange rate misalignment and its effect on trade. Kiptui and Ndirangu (2015) studied misalignment in Kenya using BEER and found that the equilibrium RER is closely associated with its long-run equilibrium level. However, Musyoki et al. (2012) found that the exchange rate was more often overvalued. Mwega (2014) sought to investigate this over-valuation in Kenya after adopting a floating exchange rate regime. Further, he argues that the equilibrium real exchange rate is an unobservable variable and must be indirectly obtained from the underlying macroeconomic variables. Contrastingly, the results showed no significant deviation of the real effective exchange rate from its estimated equilibrium rate.

Ibrahim (2014) found that between 1960 and 1985, Nigeria's real effective exchange rate was above its long-run level and below between 1986 and 2013. Similarly, Juthathip (2009) estimated misalignment in developing Asian countries and concluded that the RER was persistently overvalued in the build-up to the 1997/98 crisis. Further, the results showed that exports had a negative relationship with exchange rate misalignment. The author notes that when an RER depreciation is associated with a significant misalignment, it could positively impact exports. 
Olimov and Sirajiddinov (2008) analyzed the effect of exchange rate misalignment in Uzbekistan and found that the real exchange rate misalignment depressed exports. The results showed that import demand price elasticity was between -0.78 and -0.83 . Sidek (2011) divided a sample (1991Q1-2008Q3) into a high and low misalignment regime, respectively. The computed misalignment was incorporated alongside foreign income and relative prices in a standard export demand equation using an autoregressive framework and estimated using least squares. The study concluded that exchange rate misalignment below 8.88 percent has no significant effect on exports.

Imbs and Isabelle (2011) estimated the aggregate export and import price elasticities by applying a Constant Elasticity of Substitution (CES) demand system using annual data between 1995 and 2004. The simulated study concluded that exports had a positive relationship with relative prices. Barno, Ondaje and Ngwiri (2011) argue that this positive relationship between exports and their relative prices is possible in countries that export goods that the importing country cannot substitute easily. In another study, Ekanayake, Thaver, and Plante (2012) studied South Africa - E.U. trade by employing the error-correction model and ARDL bounds testing technique to cointegration. They found that relative prices affected imports negatively, while national income enhanced imports.

\subsection{Theoretical Framework}

\subsection{Determination of Equilibrium Exchange Rate}

Following the sticky prices, monetary theory researchers use a small set of macroeconomic fundamentals to define $Z_{t}$ in 2.12. These include terms of trade, trade openness, technological changes, government expenditure, and real interest rate. Centered on the stock-flow consistent model, the link between macroeconomic fundamentals and the real exchange rate takes the form:

$$
\operatorname{rer}^{*}=f(\text { tot }, \text { prod, gov, open })
$$

Where tot is the terms of trade, prod is technological changes as a proxy for productivity, gov is government expenditure, and open is trade openness. $\mathrm{rer}^{*}$ is the estimated real exchange rate proxied by the real effective exchange rate.

\subsection{Real Exchange Rate Misalignment and Trade Flows}

Equation 2.16 is analogous to the international trade's modified twocountry standard model, which relates imports to relative prices of imports, domestic real income, and foreign exchange reserves. The foreign exchange reserves show how export earnings can cover import demand since export earnings are a significant source of foreign reserves. Therefore, expressed as: 


$$
M_{d}=M_{d}\left(E, R P_{x}^{*}, Y, F X\right)
$$

Similarly, the foreign country's demand for imports (the domestic exports) can be expressed as: $M_{d}^{*}=M_{d}\left(E, R P_{x}, Y^{*}\right)$

\subsection{Empirical Model Specification}

\subsubsection{Determining Kenya's Exchange Rate Misalignment}

Two steps were followed to derive exchange rate misalignment: first was the estimation of equilibrium RER following the developed theoretical framework:

$$
\text { reer }_{t}^{*}=f\left(\text { tot }_{t}, \text { prod }_{t}, \text { gov }_{t}, \text { open }_{t}, \text { nfa } a_{t}, \text { tar }_{t}, \text { oil }_{t}\right)
$$

Due to the use of semi logs, the model can be specified in its multiplicative form as:

$$
\operatorname{reer}_{t}^{*}=\beta_{0} n f a^{\beta_{1}} e^{\beta_{2 p r o d} t} e^{\beta_{3 g o v}} e^{\beta_{4 t a r}} e^{\beta_{5 o i l_{t}}} e^{\beta_{6 o p e n}} e^{\beta_{7 t o t}} e^{\varepsilon_{t}}
$$

Where tot is the terms of trade, prod represents an improvement of productivity due to technological change, and gov is government expenditure, open is the degree of trade openness, $n f a$ is the net foreign assets, tar is tax revenue, and oil is the world brent oil prices. The computation of the exchange rate misalignment (Mis) was the second step involved, which followed Mwega (2014):

$$
M i s=\frac{(E R E R-R E E R)}{R E E R} * 100
$$

Where ERER is the equilibrium real exchange rate, and REER is the real effective exchange rate.

\subsubsection{The Effect of Exchange Misalignment on Trade Flows}

The misalignment variable developed in equation 3.6 is incorporated in equations 3.2 and 3.3, respectively. From the literature reviewed, the degree of trade openness (Open) was found to influence the level of imports and exports such that: $M_{d}=M_{d}\left(E, R P_{x}^{*}, Y, F X, M i s, O p e n\right)$

$$
M_{d}^{*}=M_{d}\left(E, R P_{x}, Y^{*}, \text { Mis, Open }\right)
$$

Which are specified as:

$$
\begin{aligned}
& m_{t}=\propto_{0} Y_{t}^{\alpha_{1}} R P_{t}^{\alpha_{2}} \operatorname{Open}_{t}^{\alpha_{3}} e^{\alpha_{4 F R}} e^{\alpha_{5 M i s}} e^{\alpha_{6 R E E R}} e^{\varepsilon_{t}} \\
& X_{t}=\propto_{0} Y_{t}^{* \propto_{1}} R P_{t}^{\alpha_{2}} \text { Open }_{t}^{\alpha_{3}} e^{\alpha_{4 M i s}} e^{\alpha_{5 R E E R}} e^{\varepsilon_{t}}
\end{aligned}
$$

Where $M_{t}, X_{\mathrm{t}}$ represents the value of imports and exports at time $t$, $\mathrm{Mis}_{t}$ denotes a measure of exchange rate misalignment. An increase in real income increases imports holding prices and tastes constant, and therefore the coefficient for local income $Y^{\text {local }}$ is expected to be positive. Conversely, a rise in real income of the trading partner results in more significant exports to 
those partners; hence its coefficient is expected to be positive. The effect of exchange rate misalignment is ambiguous, as shown by various studies. Therefore, the signs for $\beta_{3}$ and $\alpha_{4}$ are the subject of the study. The real exchange rate depreciation makes imports expensive, so its coefficient is expected to be negative for imports and positive for exports. The coefficient for trade liberalization (openness) is presumed to be positive.

A rise (fall) in the relative price of exports makes domestic goods less (more) competitive than foreign goods causing the demand for exports to fall (rise). However, the monetarists view that changes in relative prices of traded and non-traded goods improve exports. The main issue should not be the results but the transmission channel of the effects. The relative effect of the increase in the directly quoted exchange rate level leads to an increase in exports. Therefore, a priori, the expected sign of $\beta 1$, which measures Kenyan exports competitiveness relative to the world export prices, will be positive. According to economic theory, a rise in the relative cost of imports depresses the demand for imports. Thus, the expected sign of the coefficient is negative. Following Ekanayake, Thaver, and Plante (2012), higher real foreign reserves encourage imports, and therefore the expected sign is positive.

\subsection{Data Analysis and Estimation}

According to Engel and Granger (1987), the long-run relationship between two or more variables is checked by cointegration. As a pre-test to avoid spurious regression results, a cointegration test should be considered.

Models (3.6), (3.9), and (3.10) were augmented to implement the ARDL bound test approach as:reer $r_{j}=c+\sum_{i=1}^{p} \propto_{i} \Delta$ reer $_{t-i}+\sum_{i=1}^{p} \partial_{i} \Delta$ tot $_{t-i}+$ $\sum_{i=1}^{p} \sigma_{i} \operatorname{sprod}_{t-i}+\sum_{i=1}^{p} \delta_{i} \Delta$ gov $_{t-i}+\sum_{i=1}^{p} \gamma_{i} \Delta$ open $_{t-i}+$ $\sum_{i=1}^{p} \eta_{i} \Delta n f a_{t-i}+\sum_{i=1}^{p} \theta_{i} \Delta \operatorname{tar}_{t-i}+\sum_{i=1}^{p} \mu_{i} \Delta$ oil $_{t-i}+\lambda_{1}$ reer $_{t-1}+$ $\lambda_{2}$ tot $_{t-1}+\lambda_{3}$ prod $_{t-1}+\lambda_{4}$ gov $_{t-1}+\lambda_{5}$ open $_{t-1}+\lambda_{6} n f a_{t-1}+\lambda_{7}$ tar $_{t-1}+$ $\lambda_{8}$ oil $_{t-1}+\varepsilon_{t}$

$\Delta M_{j}=c+\sum_{i=1}^{p} \theta_{i} \Delta M_{t-i}+\sum_{i=1}^{p} \propto_{i} \Delta G D P_{t-i}+\sum_{i=1}^{p} \gamma_{i} \Delta$ open $_{t-i}+$ $\sum_{i=1}^{p} \partial_{i} \Delta$ reer $_{t-i}+\sum_{i=1}^{p} \sigma_{i} \Delta F X_{t-i}+\sum_{i=1}^{p} \gamma_{i} \Delta R P_{t-i}+\sum_{i=1}^{p} \delta_{i} \Delta M i s_{t-i}+$ $\lambda_{1} M_{t-1}+\lambda_{2}$ open $_{t-1}+\lambda_{3}$ reer $_{t-1}+\lambda_{4} F X_{t-1}+\lambda_{5}$ RPM $_{t-1}+\lambda_{6}$ Mis $_{t-1}+$ $\lambda_{7} G D P_{t-1}+\varepsilon_{t}$

$$
\begin{gathered}
\Delta X_{j}=c+\sum_{i=1}^{p} \theta_{i} \Delta X_{t-i}+\sum_{i=1}^{p} \propto_{i} \Delta G D P_{t-1}^{f}+\sum_{i=1}^{p} \gamma_{i} \Delta R P_{t-i}+ \\
\sum_{i=1}^{p} \partial_{i} \Delta \text { reer }_{t-i}+\sum_{i=1}^{p} \sigma_{i} \Delta \text { Open }_{t-i}+\sum_{i=1}^{p} \delta_{i} \Delta M i s_{t-i}+\lambda_{1} X_{t-1}+ \\
\lambda_{2} \text { open }_{t-1}+\lambda_{3} \text { reer }_{t-1}+\lambda_{4} R P X_{t-1}+\lambda_{5} \text { Mis }_{t-1}+\lambda_{6} G D P_{t-1}^{f}+\varepsilon_{t}
\end{gathered}
$$


The calculated $F$-statistic for the joint significance of lagged variables was used to test for cointegration between the variables in models (3.11) to (3.13). The two sets of the adjusted critical value bound as $\mathrm{I}(0)$ and $\mathrm{I}(1)$ as lower and upper bound, respectively, were adopted as prescribed by Pesaran Shin and Smith (2001). According to the bounds test, if the lower bound is above the computed $F$-statistic, then regardless of whether the variables are $\mathrm{I}(0), \mathrm{I}(1)$, the null hypothesis of no cointegration cannot be rejected. In case the upper bound is below the computed $F$-statistic, then the null hypothesis is rejected. The cointegration results are considered inconclusive if the computed $F$-statistics fall amid the two bounds.

\subsection{Results}

This chapter is divided into sections consisting of descriptive statistics, tests result of time series properties, and diagnostic tests on estimated models.

\subsection{Descriptive Statistics}

Table 1: Descriptive Statistics

\begin{tabular}{|c|c|c|c|}
\hline Variable & Mean & Minimum & Maximum \\
\hline Foreign Reserves (F.R.) (KES Billion) & 299.38 & 61.30 & 818.30 \\
\hline $\begin{array}{l}\text { Gross Domestic Income (GDP)- } \\
\text { Kenya (KES Billion) }\end{array}$ & 705.16 & 242 & $1,929.30$ \\
\hline $\begin{array}{l}\text { Gross Domestic income -EU (GDP } \\
\text { foreign) (Billion Euros) }\end{array}$ & $3,101.08$ & $2,368.10$ & $3,740.20$ \\
\hline $\begin{array}{l}\text { Government expenditure (Gov) \% of } \\
\text { GDP }\end{array}$ & 0.83 & 0.18 & 3.03 \\
\hline $\begin{array}{l}\text { Net Foreign Assets (NFA) (KES } \\
\text { Billion) }\end{array}$ & 251.62 & 58.50 & 591.90 \\
\hline Crude Oil Prices (Oil) (USD/Barrel) & 64.92 & 19.34 & 122.48 \\
\hline Imports from EU (M) (KES Billion) & 22.83 & 10.27 & 40.11 \\
\hline Exports to EU (X) (KES Billion) & 17.82 & 7.54 & 31.08 \\
\hline Tax Revenue (TAR) (\%) of GDP & 0.43 & 0.14 & 1.06 \\
\hline $\begin{array}{l}\text { Relative Prices of Imports (RPM) } \\
\text { ratio of domestic import prices to } \\
\text { world import prices }\end{array}$ & 0.09 & 0.05 & 0.11 \\
\hline $\begin{array}{l}\text { Relative Prices of Exports (RPX) ratio } \\
\text { of domestic export prices to world } \\
\text { export prices }\end{array}$ & 0.03 & 0.02 & 0.04 \\
\hline Real Effective Exchange Rate (REER) & 78.59 & 58.17 & 109.88 \\
\hline $\begin{array}{l}\text { Trade Openness (Open) }(\mathrm{X}+\mathrm{M})(\%) \text { of } \\
\text { GDP }\end{array}$ & 15.73 & 9.07 & 30.01 \\
\hline $\begin{array}{l}\text { Terms of Trade (ToT) ratio of export } \\
\text { prices to import prices }\end{array}$ & 0.43 & 0.30 & 0.64 \\
\hline $\begin{array}{c}\text { Productivity (Prod) (\%) gross capital } \\
\text { investment to GDP }\end{array}$ & 19.34 & 16.20 & 22.5 \\
\hline
\end{tabular}

Source: Author's computations. 
Kenya's GDP ranged from KES 242 billion in 2000Q2 to KES 1,929.3 billion in 2016Q2, with a mean of KES 705.2 billion between 2000 and 2016. The GDP value increased drastically from KES 343.5 billion in 2008Q4 to KES 701.9 billion in 2009Q1 due to a change of the base year from 2001 to 2009 in the System of National Accounts (Republic of Kenya 2015). The mean foreign national income was 3,101.081 billion euros with a minimum of 2368.1 and a maximum of 3740.2. The EU GDP grew persistently between 2000 and 2016, with a notable dip in 2008 attributed global financial crisis of 2007 - 2010.

Government expenditure has been on an upward trend averaging 83 percent of national income with a maximum of 303 percent in Q2 of 2013. The 2013/14 fiscal year was the first year of devolution marked with massive government transfers towards forming and setting up devolved government authorities. While government expenditure remained relatively stable between 2000 and 2007, it has accelerated since then. National foreign exchange reserves averaged KES 299.38 billion between 2000 and 2016, with a minimum of 61.3 billion and a maximum of 818.3billion. A country's National foreign exchange reserves indicate the country's capacity to import and is calculated at the prevailing exchange rate were highest in 2016 Q2 at KES 818 billion and lowest in 2000 Q1 at KES 61 billion.

\subsection{Unit root, Cointegration, and Diagnostic tests}

Data stationarity or non-stationarity is primarily determined before regression analysis. It eliminates the danger of finding significant regression results from unrelated data if a non-stationary data series is utilized in regression analysis. Spurious results may be obtained by including nonstationary variables in regression models. The $R$-square values and $t$-statistics do not follow the normal distributions and can be widely inflated. If nonstationary time series are used in a regression model, the results may show a significant relationship where none exists. The use of time-series data makes it necessary to establish the stationarity or non-stationarity of the data. ADF and P.P. tests are associated with low power against stationary near unit root processes. Therefore, Kwiatkowski Phillips, Schmidt and Shin (KPSS) was more appropriate.

The results show that Foreign exchange reserves, local, national income, foreign national income, real effective exchange rate, terms of trade, net foreign assets, productivity, the relative price of imports, tax revenue, world oil prices, trade openness, exports, and imports were stationary at the first difference I(1) while government expenditure, exchange rate misalignment, and the relative price of exports were $\mathrm{I}(0)$. Since none of the variables integrated order two I(2), the ARDL technique was most appropriate 
since it does not require the same order of integration, and none of the variables should be integrated of order I(2).

Since the variables were integrated of order I(0) and I(I), the ARDL bounds test was considered the most appropriate method to test for cointegration. The bounds test results for all the models used are summarized in Table 2. The computed $F$-statistics were matched with the bounds critical values at the optimal lags $(\mathrm{k})$. Co-integration was established in REER, exports, and Imports models since the $F$-statistics was above the upper bound.

\section{REER}

Table 2. ARDL Bounds Test

Null Hypothesis: No long-run relationships exist

\begin{tabular}{ccc}
\hline \hline Test Statistic & Value & $\mathrm{k}$ \\
F-statistic & 4.659491 & 7 \\
& Critical Value Bounds & \\
\hline \hline Significance & I0 Bound & I1 Bound \\
$10 \%$ & 2.03 & 3.13 \\
$5 \%$ & 2.32 & 3.5 \\
$2.5 \%$ & 2.6 & 3.84 \\
$1 \%$ & 2.96 & 4.26
\end{tabular}

Null Hypothesis: No long-run relationships exist

\begin{tabular}{ccc}
\hline \hline Test Statistic & Value & $\mathrm{k}$ \\
F-statistic & 4.703397 & 6 \\
& Critical Value Bounds & \\
\hline \hline Significance & I0 Bound & I1 Bound \\
$10 \%$ & 2.12 & 3.23 \\
$5 \%$ & 2.45 & 3.61 \\
$2.5 \%$ & 2.75 & 3.99 \\
$1 \%$ & 3.15 & 4.43 \\
Exports & & \\
\hline \hline Test Statistic & Value & $\mathrm{k}$ \\
F-statistic & 5.325480 & 5 \\
Critical Value Bounds & \\
\hline \hline Significance & I0 Bound & I1 Bound \\
$10 \%$ & 2.26 & 3.35 \\
$5 \%$ & 2.62 & 3.79 \\
$2.5 \%$ & 2.96 & 4.18 \\
$1 \%$ & 3.41 & 4.68 \\
\hline \hline
\end{tabular}

Source: Author's computations.

To ensure consistent and unbiased regression results, various diagnostic tests, including normality test using Jarque Bera statistics, serial correlation Breuch-Godfrey Lagrange Multiplier (L.M.) test, autoregressive conditional heteroskedasticity (ARCH) test, RESET test for model specification, and CUSUM test for parameter constancy were conducted. 
Table 3. Residual Properties

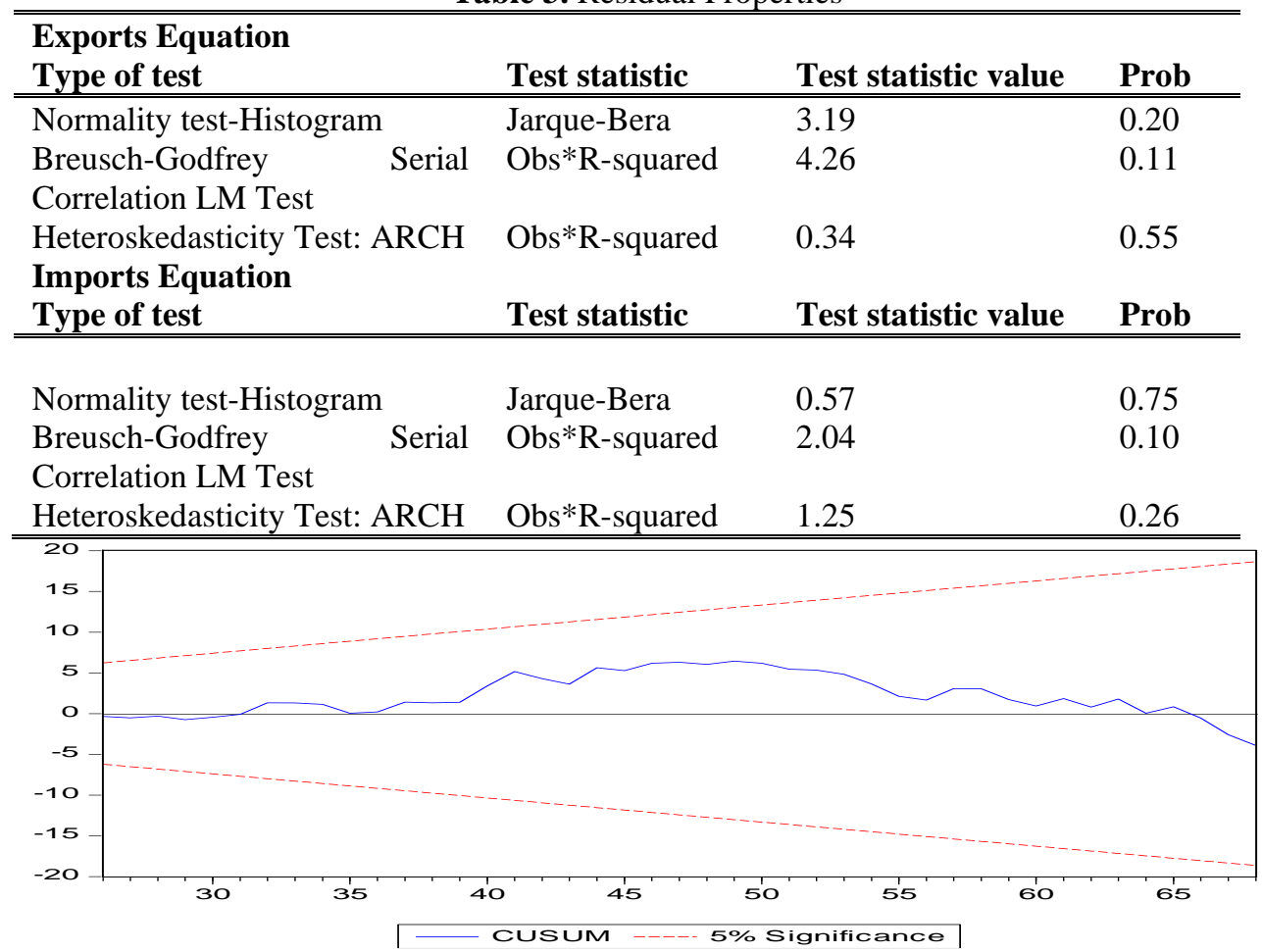

Figure 2 : CUSUM Test for REER Equation

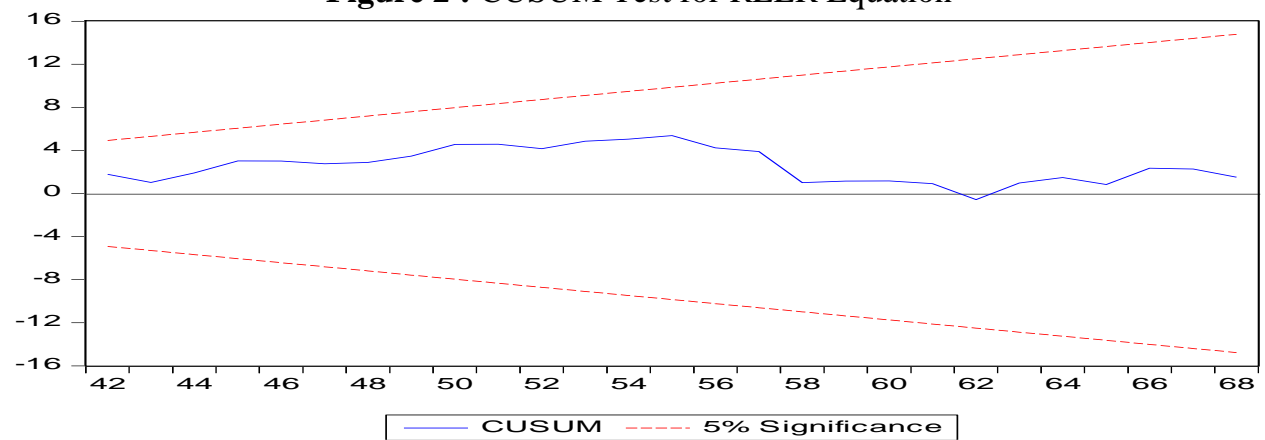

Figure 3 : CUSUM Test for the Import Equation

\subsection{Determining the Extent of Kenya's Real Exchange Rate Misalignment}

Model 3.11 was estimated, and the ARDL long-run coefficients of the determinants of exchange rate are presented in Table 4. 
Table 4: Long-Run effects of Economic Fundamentals on Real Effective Exchange Rate

\begin{tabular}{|c|c|c|}
\hline \multicolumn{3}{|c|}{ Dependent Variable - log of Real Effective Exchange Rate } \\
\hline Explanatory Variable & Coefficient & Standard Error \\
\hline Government expenditure & 0.071 & 0.05 \\
\hline Log of Net Foreign Assets & $0.415 * *$ & 0.17 \\
\hline Log of Productivity & $0.354 * * *$ & 0.13 \\
\hline Tax Revenue & -0.119 & 0.09 \\
\hline Oil Prices & $-0.001 * * *$ & 0.00 \\
\hline Openness & $0.015 * *$ & 0.01 \\
\hline Terms of Trade & $0.004 * *$ & 0.00 \\
\hline
\end{tabular}

From the results, macroeconomic fundamentals determine the real effective exchange rate except for government expenditure and tax revenue. The coefficients on government expenditure and tax revenue were positive and negative respectfully but statistically insignificant at any level. The results show that a one percent increase in the net foreign assets depreciates the REER by 0.41 percent. According to economic theory, the exchange rate positively correlates with shocks on the net foreign asset position. This Effect results from the transfer effect where the transfer of external wealth into the domestic economy has a strong positive relationship with the exchange rate in the long run.

A one percent productivity improvement leads to a 0.35 percent depreciation of the REER. In theory, increased productivity leads to a real exchange rate appreciation. However, according to Balassa and Samuelson (1964), the effect depends on whether the productivity is traded or non-traded. While the expected result was an appreciation, productivity can also bring a real exchange rate depreciation if the resultant offer effect is greater than the income effect. According to Edwards (1989), an increase in technical progress in developing countries depreciated the real exchange rate because their main traded sector is the agricultural sector, and the rate of technological progress is slow.

A unit percent increase in the prices of world brent oil leads to a 0.1 percent appreciation of the REER. Kenya is a net importer of oil, and the bulk of imports comprises oil, and the country's non-tradeable sector is more significant than the tradeable sector. Any upward movement in oil prices puts increasing pressure on local prices to go up, appreciating the exchange rate. An increase in openness favors the more robust economy, in this case, E.U. thus more imports than exports. The increased imports lower the price of tradeable goods in the domestic economy. According to purchasing power parity theory, tradeable goods become cheaper to foreigners depreciating the local currency. The results show that openness constrains policymakers' 
incentives to stabilize the domestic currency in real terms. Similar results by Nkalu, Urama and Asogwa (2016) in Nigeria indicate that trade openness was a significant variable and contributed up to 59 percent to the depreciation of the Naira.

About the terms of trade, a one percent increase in terms of trade leads to a 0.4 percent depreciation of the REER. According to Imed and Christophe (2003), the effect of terms of trade on the real exchange rate is theoretically ambiguous. It depends on the relative magnitude of the substitution effect and income effect. The results exhibit an indirect substitution effect which induces a variation of the demand of the non-tradeable goods where terms of trade improvement provide currency resources necessary to produce more nontradeable goods. The long-run estimates of the economic fundamentals were then used to obtain the fitted values of the equilibrium real exchange rates (ERER). The exchange rate misalignment (Mis) was hence computed following Mwega (2014) as: $M i s=\left(\frac{E R E R-R E E R}{R E E R}\right) * 100$. The ERER is the estimated equilibrium exchange rate proxied by the fitted values. Figure 4 plots the misalignment values in percentages.

Figure 4. Real Exchange Rate Misalignment

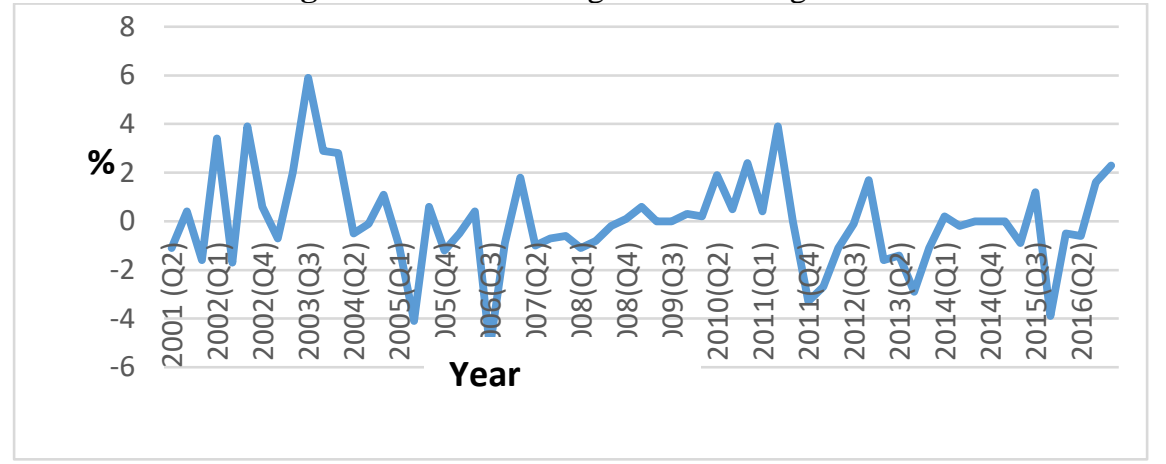

Source: Author's computations

The period between 2001 to 2004 and 2009 to 2011 shows significant overvaluation of Kenya's exchange rate. The change in government in 2003 could be attributed to the low misalignment between 2004 and 2008 and the prolonged exchange rate appreciation. The exchange rate misalignment in the period considered was 5.9 percent overvaluation. The maximum undervaluation was 5.2 percent. The real exchange rate is misaligned, but within the 6 percent range, the results are similar to Kiptui and Ndirangu (2015), who found that Kenya's exchange rate misalignment was within 10 percent of its equilibrium level. 


\subsection{The Effect of Exchange Rate Misalignment on Bilateral Trade Flows between Kenya and E.U.}

Table 5. Long-run Effects of Exchange Rate Misalignment on trade flows

\begin{tabular}{|c|c|c|c|c|}
\hline \multirow[t]{4}{*}{ Explanatory variables } & \multicolumn{4}{|c|}{ Dependent Variable } \\
\hline & \multicolumn{2}{|c|}{ Log of Imports } & \multicolumn{2}{|c|}{ Log of exports } \\
\hline & & Standard & & Standard \\
\hline & Coefficients & Error & Coefficient & Error \\
\hline Log of Real GDP & $0.489 * *$ & 0.164 & & \\
\hline Log of real GDP foreign & & & $10.058 * * *$ & 4.203 \\
\hline Relative Prices & $-0.499 * * *$ & 3.137 & & \\
\hline Log of Relative Prices & & & $0.915 * * *$ & 0.160 \\
\hline Foreign Reserves & 0.023 & 0.005 & & \\
\hline Misalignment & $-0.131 * *$ & 0.060 & 0.035 & 0.004 \\
\hline Log of trade Openness & 0.305 & 0.241 & $0.378 * * *$ & 0.342 \\
\hline Real Effective Exchange Rate & $-0.029 * * *$ & 0.018 & & \\
\hline Log of Real Effective & & & 1.054 & \\
\hline Exchange Rate & & & & 0.660 \\
\hline
\end{tabular}

A one percent increase in Kenya's GDP increases imports by 0.49 percent. A country's imports depend on its level of income such that the higher the level of income (holding prices of imports and consumer tastes constant), the greater the imports. Gaalya, Edward, and Eria (2017) found that imports in the EAC members are income inelastic (concentrated between 0.4 and 0.07). Further, GDP per capita has a higher influence on consumer goods than capital and intermediate goods, explaining the low-income elasticity. For foreign income, a unit increase in foreign income increases exports by 10 percent. According to Gaalya et al. (2017), GDP per capita has a higher influence on consumer goods than capital and intermediate goods. Kenya's exports to E.U. are mainly consumer goods which could explain the high elasticity of income.

A unit increase in relative prices of imports reduces Kenya's imports by 49 percent. Since Kenya's imports from E.U, China has offered an alternative avenue to source for motor vehicles and accessories, human medicine and agricultural chemicals, steel and iron products, rubber, computers and accessories, veterinary products, fuels and lubricants, and electrical and electronic equipment, Therefore, an increase in import prices likely causes Kenya to shift imports from E.U. to alternative markets such as China. In 2000, imports from China amounted to a paltry KES 7.76 billion while imports from E.U. amounted to KES 75.65 billion. In 2016, imports from China amounted to KES 337.45 billion while imports from E.U. amounted to KES 212.57 billion (Republic of Kenya 2004, and 2019). 
Regarding relative prices of exports, the coefficient of 0.915 is positive and statistically significant at a 1 percent level implying a one percent increase in relative prices of the exports raises Kenya's exports to E.U. by 0.9 percent. Imbs and Isabelle (2011) argue that the response of exports due to relative price changes depends on the willingness of the consumer to substitute domestic and foreign goods. In the case of good in-substitutability, an increase in price does not adversely affect exports. These results indicate that Kenya's exports to E.U. are non-substitutable. According to Barno, Ondaje and Ngwiri (2011), Kenya is among the world's producers of specialty vegetables. In addition, globalization has seen changes in consumer food demand where consumers are considering all year-round food supplies produced by extensive agricultural techniques with a strong ethical component. This has led to consumers considering quality over price. The results reflect the reality where Kenya's green beans are among the world's best while snow peas have replaced Asian vegetables in the world market.

A one percent increase in misalignment reduced imports by 13 percent. The results show that Kenyan importers are risk-averse, and being a developing country with no structured foreign exchange, the avenue for hedging is either expensive, impossible, or both. The exchange rate misalignment coefficient of 0.035 for exports is positive and statistically insignificant similar to Ibrahim (2014). Sidek (2011) indicated that any misalignment has no statistical significance on exports below 8.88 percent. Juthathip (2009) notes that the insignificance of the export coefficient can be explained by the lack of diversification in Kenya's goods for exports because diversification increases the significance and magnitude of the misalignment coefficient. Trade openness has a positive but insignificant coefficient for imports. According to Manni (2012), although greater trade openness is expected to enhance a country's imports and exports, it does not imply both must increase. However, for Kenya's exports to the E.U., the trade openness coefficient implies a one percent increase in trade openness increases exports by 0.378 percent. The small magnitude could be explained by the limited number of countries Kenya trades within the E.U. and the lack of diversification of her trade goods. Results indicate that one unit of depreciation decreases imports by 2.9 percent. Theoretically, depreciation of the domestic exchange rate against a foreign currency makes imports expensive and exports competitive.

\section{Conclusion}

Kenya's exchange rate can be considered closely aligned to its longrun macroeconomic fundamentals. The actual RER rate had more episodes of undervaluation during the study period than overvaluation. The misalignment 
was detected and was within a 6 percent deviation from the long-run equilibrium level.

The study also examined the effect of exchange rate misalignment among other economic variables on imports and exports between Kenya and E.U. From the results, exchange rate misalignment inhibits Kenya's imports from E.U. while it did not affect exports. Therefore, Kenyan exports are not diversified, reducing the significance and magnitude of the effect on exports. Additionally, Kenyan importers are risk-averse and reduce their activities with increased exchange rate misalignment. In small economies, hedging instruments are not available, and where they are available, they are costly or complex to apply in small firms.

In line with economic theory, domestic income enhanced imports. According to the East Africa Community (EAC) member states, the income elasticity is concentrated between 0.4 and 0.07 . Further, the results show a high foreign income elasticity implying that Kenya's imports are capital and intermediate goods, which exhibit low-income elasticity. The exports are consumer goods characterized by higher elasticity. Similar to other developing countries, Kenya's exports respond well to changes in trading partners' incomes. In particular, fresh food products have a high-income elasticity of demand in higher-income markets such as the E.U. Consequently, it represents an important opportunity for Kenyan exporters since fresh fruits and vegetable exports account for the bulk of all food and agricultural exports to the E.U. The results show that Kenya's exports respond positively to an increase in relative prices of exports which shows in substitutability of imported goods to locally produced goods in the E.U. It can be concluded that Kenya's exports are specialties in E.U., especially French beans, snow peas, and cut flowers.

Although trade openness improves imports and exports, the coefficient was only significant for exports meaning the nonreciprocal trade arrangement between Kenya and E.U. under the ACP framework favors E.U. However, the magnitude was tiny typical of developing countries because they have a limited number of export goods and are of raw materials nature and a small menu of export destinations in E.U. Therefore, the EU-ACP non reciprocal agreement failed to consider the trade patterns between the partners. Kenya has not gained significantly from this agreement.

\section{Research Limitations and Areas of Future Research}

The study limited the scope to the Effect of exchange rate on trade flows between Kenya and E.U. Therefore, further research should be pursued for other economic blocks such as EAC, COMESA, and other emerging trade destinations like China. Also, researchers should evaluate the EPAs trade arrangement along with some of the findings from the study. 


\section{References:}

1. Arize, A., Osang, T., \& Slottje, D. (2008). Exchange-Rate Volatility in Latin America and its Impact on Foreign Trade. International Review of Economics and Finance Volume 17 (1) 133-44.

2. Bahmani, M. O., Harvey, M., \& Hegerty, S. W. (2012). Exchange-rate Volatility and Industry Trade Between the U.S. and Korea. Journal of Economic Development, 37(1).

3. Balassa, B., (1964). The Purchasing-Power Parity Doctrine: A Reappraisal. Journal of Political Economy Vol. 72, No. 6 (Dec., 1964), pp. 584-596.

4. Barno, A., Ondaji, B., \& Ngwiri, J. (2011). Dynamics of horticultural export to European Union market: Challenges and opportunities in Sub-Saharan Africa. Acta orticulturae 911(911):61-72.

5. Bird, G. (1998). Exchange Rate Policy in Developing Countries: What Is Left of the Nominal Anchor Approach? Taylor \& Francis, Ltd. Third World Quarterly, No. 2 (19) (Jun., 1998), pp. 255-276.

6. Calamitsis, E., Basu, A., \& Ghura, D. (1999). "Adjustment and Growth in Sub-Saharan Africa." IMF Working Paper Series 99/51. Washington, DC: International Monetary Fund.

7. Calderon, C. A., Chong, A., \& Loayza, N. (2002). "Determinants of current account deficits in developing countries." The B.E. Journal of Macroeconomics 2, no. 1: 1-31.

8. Cote, A. (1994). Exchange rate volatility and trade A survey. Bank of Canada Working Paper 94-5.

9. Csermely, A. (1994). The Impact of Exchange-Rate Policy on the Development of Industrial Competitiveness. Russian \& East European Finance and Trade, Vol. 30(6), pp. 6-27.

10. Dornbusch, R. (1976). Expectations and Exchange Rate Dynamics. Journal of political Economy. 84 (6), 1161-1176.

11. Edwards, S. (1989). "Exchange Rate Misalignment in Developing Countries," UCLA Economics Working Papers 442, UCLA, Department of Economics.

12. Edwards, S. (1997). The Mexican Peso Crisis: How Much Did We Know? When Did We Know It? National Bureau of Economic Research. Working Paper 6334.

13. Ekanayake, E. M., Thaver, R. L., \& Plante, D. (2012). The effects of exchange rate volatility on South Africa's trade with the European Union, The International Journal of Business and Finance Research, 6(3), 13-26.

14. Gaalya, M. S. Edward, B., \& Eria, H. (2017). Trade Openness and Dissagregated Import Demand in East African Countries. Scientific Research Publishing, 2017 (8) 667-689. 
15. Ibrahim, W. (2014). Real Exchange Misalignment and Trade Flows in Nigeria (1960-2013). Journal of Academic Research in Economics, Vol 6 (3).

16. Imbs, J., \& Isabelle M. (2011). "Trade Elasticities," August 2011, mimeo, Paris School of Economics and Ecole Polytechnique.

17. Juthathip, J. (2009). Equilibrium Real Exchange Rate, Misalignment, and Export Performance in Developing Asia. Asian Development Bank, Working Papers 151.

18. Kiptui, M. C., \& Kipyegon, L. (2008). External Shocks and Real Exchange Rate Movements in Kenya. The 13th Annual Conference on Econometric Modelling in Africa 9-11 July 2008: University of Pretoria.

19. Kiptui, M.C., \& Ndirangu, L. (2015). Determinants of Equilibrium Real Exchange Rate and its Misalignment in Kenya: A Behavioral Equilibrium Exchange Rate Approach, MPRA Paper No. 70542, https://mpra.ub.uni-muenchen.de/70542/

20. Lugaiyamu, L. (2015). Determinants of Exchange Rate in Tanzania. (unpublished). Uppsala University.

21. Manni, U. H., \& Afzal M. N. I. (2012). Effects of Trade Liberarization on Economic Growth of Developing Countries: A case of Bangladesh Economy. Journal of Business, Economics and Finance Vol 1(2).

22. Musyoki, D., Pokhariyal G. P., \& Pundo, M. (2012). Real Exchange Rate Equilibrium and Misalignment in Kenya. Journal of Business Studies Quarterly, Vol 3, No, 4, 24-42.

23. Mukherjee, D., \& Pozo, S. (2007). Exchange-Rate Volatility and Trade: A Semiparametric Approach. Applied Economics. Vol 43, (13).

24. Mwangi, S. C., Mbatia, O. L. E., \& Nzuma, J. M. (2014). Effects of Exchange Rate Volatility on French Beans Exports in Kenya. Journal of Agricultural Economics, Extension and Rural Development, 1(1), $1-12$.

25. Mwega, F., M. (2014). Real Exchange Rate Misalignment and Implications for the Nominal Exchange Rate Level in Kenya in 2012. Central Bank of Kenya.

26. Naseem, N. A. M, Tan, H., \& Hamizah, M.S. (2009). Exchange Rate Misalignment, Volatility and Import Flows in Malaysia. International Journal of Economics and Management 3(1): 130 - 150

27. Nkalu, N., Urama, N.E., \& Asogwa, F. (2016). Trade openness and Exchange Rate Fluctuations Nexus in Nigeria. European Journal of Scientific Research vol 138 (3), 139

28. Nkoro, E., \& Uko, A. (2016). Auto Regressive Distributed Lag (ARDL) Cointegration Technique: Application and Interpretation. Journal of Statistical and Econometric Methods Vol 5 (4) 63-91. 
29. Oiro, M. O. (2015). Real Exchange Rate Volatility and Exports in Kenya: 2005-2012. Journal of World Economic Research. Vol. 4, No. 5, 2015, pp. 115-131.

30. Olimov, U., \& Sirajiddinov, N. (2008). The Effects of the Real Exchange Rate Volatility and Misalignment on Foreign Trade Flows in Uzbekistan. Discusion Paper 2008-29, Center for Economic Research, Tushkent, Uzbekistan.

31. Pesaran, M. H., Shin, Y. \& Smith, R. J. (2001). Samuelson Bounds Testing Approaches to the Analysis of Level Relationships; Journal of Applied Econometrics, Vol. 16, 2001, pp. 289-326.

32. Republic of Kenya. (2004). Economic survey. Nairobi: Government printer.

33. Republic of Kenya. (2007). Economic survey. Nairobi: Government printer.

34. Republic of Kenya. (2012). Economic survey. Nairobi: Government printer.

35. Republic of Kenya. (2014). Economic survey. Nairobi: Government printer.

36. Republic of Kenya. (2015). Economic survey. Nairobi: Government printer.

37. Republic of Kenya. (2017). Economic survey. Nairobi: Government printer.

38. Republic of Kenya. (2019). Economic survey. Nairobi: Government printer.

39. Sidek, N.Z. (2011). Malaysia: How Much Exchange Misalignment is Detrimental to Exports?. International Conference in Economics, Trade and Development. IPEDR Vol 7.

40. Siregar, R. Y. (2011). The Concepts of Equilibrium Exchange Rate: A Survey of Literature. The South East Asian Central Banks (SEACEN). Kuala Lumpur, Malaysia.

41. Sultan, Z.A. (2011). Foreign Exchange Reserves and India's Imports Demand. A Cointegration and Vector Error Correction Analysis. International Journal of Business and Management Vol 6 (7).

42. World Bank. (2012). Can Real Exchange Rates Undervaluation Boost Exports and Growth in Developing Countries? Yes, but not for Long. Poverty Reduction and Economic Management Network (PREM). World Bank. Washington. Issue 10. 